\title{
Use of obstetric gel in nulliparous pregnant women: Maternal and neonatal outcomes
}

\author{
Burçhan Aydıner', Hüseyin Kıyak', Fatih Mete², Ali Ekiz', İbrahim Polat' ${ }^{1}$ Ali Gedikbasi' \\ ${ }^{1}$ Gynecology and Obstetrics Clinic, Kanuni Sultan Sïleyman Training and Research Hospital, Health Sciences University, Istanbul, Turkey \\ ${ }^{2}$ Pediatrics Clinic, Kanuni Sultan Siileyman Training and Research Hospital, Health Sciences University, İstanbul, Turkey
}

\begin{abstract}
Objective: The study aims to investigate the effects of obstetric gel application on the first and second stages of labor in nulliparous pregnant women, the presence of its protective effect on perineum and fetal and maternal outcomes associated with this method.

Methods: The nulliparous pregnant women who admitted to our hospital between 37 and 41 weeks of gestation were randomized into two groups, which were those applied gel and those not applied. During their labors, pregnant women were not administered any labor induction or augmentation; they underwent routine amniotomy, but routine episiotomy was not performed during labor. Both groups were compared in terms of perineal laceration, episiotomy need, periods of labor stages, laboratory data, and newborn data.

Results: A total of 200 nulliparous pregnant women (Group I: $\mathrm{n}=102$, spontaneous follow-up; Group II: $\mathrm{n}=98$, gel-applied) who were complying with study criteria were evaluated. No difference was found in maternal demographic data, laboratory data and newborn results. In gel-applied patients, the first and second stages of labor were shorter and they were statistically significant. In terms of episiotomy procedure / need, there was no difference between the groups. In terms of cases where laceration did not occur and mild perineal lacerations (1st and 2nd degrees), the results were relatively better in gel-applied pregnant women, and no statistical difference was found in advanced perineal lacerations (3rd and 4th degrees).

Conclusion: Use of obstetric gel during labor in nulliparous women provides a significant reduction in labor stages and there are fewer lacerations.
\end{abstract}

Keywords: Labor facilitation, labor stages, obstetric gel.

\section{Introduction}

The most important risk factors for pelvic organ prolapse and urinary incontinence are the injury of pelvic floor together with the lacerations of pelvic muscles, particular-

\section{Özet: Nullipar gebelerde obstetrik jel kullanımı: Maternal-neonatal sonuçları}

Amaç: Obstetrik jel uygulamasının nullipar gebelerde, travayın birinci ve ikinci evresi üzerine etkisi, perine üzerine koruyucu etkisinin varlığı ve bu yönteme bağlı fetal ve maternal sonuçlarını araştırmak amaçlanmıştır.

Yöntem: Hastanemize 37-41 gebelik haftalarında başvuran nullipar gebeler randomize edilerek jel uygulanan ve uygulanmayanlar olmak üzere gruplar oluşturuldu. Gebelere travayları boyunca doğum indüksiyonu veya augmentasyonu verilmedi, rutin amniyotomi uygulandı, doğum sırasında rutin epizyotomi uygulanmadı. Her iki grup perineal laserasyon, epizyotomi gereksinimi, doğum evrelerinin süreleri, laboratuvar verileri ve yenidoğan verileri açısından karşılaştırıldı.

Bulgular: Çalışma kriterlerine uygun 200 nullipar gebe (Grup I: $\mathrm{n}=102$, spontan izlem; Grup II: $\mathrm{n}=98$, jel uygulanan) değerlendirildi. Maternal demografik verileri, laboratuvar verileri ile yenidoğan sonuçlarında herhangi bir fark saptanmadı. Jel uygulanan hastalarda doğumun birinci ve ikinci evre süreleri istatistiksel açıdan anlamlı olarak kısa saptandı. Epizyotomi uygulaması / gereksinimi açısından gruplar arasında herhangi bir fark saptanmadi. Laserasyonun oluşmadığı durumlar ile hafif perineal laserasyonlar (1. ve 2. derece) açısından jel uygulanan gebelerde sonuçlar göreceli olarak daha iyi olarak değerlendirilirken, ileri derece perineal laserasyonlarda (3. ve 4. derece) istatistiksel fark saptanmadi.

Sonuç: Nulliparlarda travayda obstetrik jel kullanımı, doğum evrelerinde anlamlı bir kısalma sağlarken, daha az laserasyonlar görülmektedir.

Anahtar sözcükler: Doğumun evreleri, doğumun kolaylaştırılması, obstetrik jel.

ly $\mathrm{m}$. levator ani. ${ }^{[1]}$ Many risk factors such as hormonal changes during pregnancy, maternal age, fetal birth weight etc. are considered as the factors accounted for pelvic floor dysfunction. In addition, the second stage of
Correspondence: Ali Gedikbaşı, MD. Gynecology and Obstetrics Clinic, Kanuni Sultan Süleyman Hospital, Health Sciences University, İstanbul, Turkey. e-mail: alged_1971@yahoo.com

Received: November 2, 2017; Accepted: December 7, 2017

Please cite this article as: Aydıner B, Kıyak H, Mete F, Ekiz A, Polat İ, Gedikbasi A. Use of obstetric gel in nulliparous pregnant women: Maternal and neonatal outcomes.

Perinatal Journal 2017;25(3):127-132.

(C2017 Perinatal Medicine Foundation
Available online at: Available online at:
www.perinataljournal.com/20170253009
doi:10.2399/prn.17.0253009 QR (Quick Response) Code:

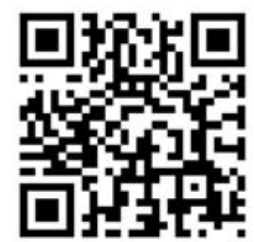


labor and its extension are considered as the most important obstetric factors for the injury and dysfunction of pelvic floor. ${ }^{[2]}$ The extended second stage of labor increases operative vaginal labor rates and it is associated with the undesired peripartum morbidity of newborn..$^{[3]}$

Decreasing operative vaginal labor rates by the limited episiotomy procedure or forceps / vacuum application rather than routine procedure may help to decrease pelvic floor injury during labor. ${ }^{[4]}$ Apart from that, it has been shown by randomized controlled studies and Cochrane analyses that perineal massage before or during labor provides protection against pelvic floor injury and decreases postpartum perineal pain. ${ }^{[5]}$

Obstetric gels are liquid-based gels generally developed to facilitate vaginal labor. The purpose of the procedure is to facilitate the fetus delivery for pregnant woman and to protect perineal area and pelvic floor. Obstetric gel decreases the friction between fetus and vagina by its lubricating effect on birth canal. In this way, it is reported that it decreases labor duration for $30 \%$ (mean: 26 minutes) both in nulliparous and multiparous women and protects vagina, pelvic floor and perineum of mother. ${ }^{[6]}$ It was also reported that use of obstetric gel together with perineal massage significantly prevents perineal lacerations. ${ }^{[7]}$ In our study, we investigated the effects of obstetric gel on perineum and labor.

\section{Methods}

The ethics approval of this prospective and randomized controlled study was obtained from Zeynep Kamil Training and Research Hospital (24.06.2016, Decision No. 144). The cases were chosen among the patients who admitted to our hospital between August and October 2016 by evaluating them against the inclusion criteria and taking their consents.

The inclusion criteria were as follows: $18-40$ years old, nulliparous, term, singleton, vertex presentation, not having any obstetric and systemic pathology, not undergoing cervical surgery, body mass index (BMI) being $20-30 \mathrm{~kg} / \mathrm{m}^{2}$, not having fetal anomaly or growth retardation and estimated birth weight being between 2000 and $4500 \mathrm{~g}$. According to these criteria, we categorized the cases in two groups:

- Group I: The control group whose labors were followed up spontaneously; no application was performed.

- Group II: The study group who were applied obstetric gel.
We used random numbers method on MedCalc for randomizing the patient groups. Accordingly, we applied Natalis ${ }^{\mathrm{TM}}$ once, which is both oil- and water-based Formula in gel form, to the study group. Natalis ${ }^{\mathrm{TM}}$ gel is a mixture containing propylene glycol, hydroxyethyl cellulose, sodium chlorite, glycerol and xanthan gum (contains mostly hydroxyethyl cellulose and glycerol). The related gel was applied $15 \mathrm{ml}$ by the disposable sterile syringe and applicator on cervix and adjacent area when the first stage of labor started, in the presence of active contractions and when cervical dilatation was $4 \mathrm{~cm}$, and routine primigravida follow-up protocol was performed. On the other hand, only the standard labor protocol, which is performed for primigravida pregnant women, was performed for the patients in the control group.

Depending on the current gel amount we had, we only estimated it to be used on 105 patients for both groups ( $\mathrm{n}=210)$; 3 patients in Group I and 7 patients in Group II were taken to emergency operative labor until the end of labor due to the fetal distress. As a result, Group I and Group II consisted of 102 and 98 patients, respectively, in our study.

In our study, we did not perform additional procedures which may affect or extend the stages of labor in the cases by not applying epidural anesthesia or additional analgesics.

For statistical analyses, we used MedCalc (version 13.3; Mariakerke, Belgium) statistics software. For comparing descriptive statistical methods (mean, standard deviation, rate, minimum, maximum) as well as quantitative data when evaluating study data, we used Student $t$ test in the two-group comparison of parameters displaying normal distribution, and Mann-Whitney $U$ test in the two-group comparison of parameters not displaying normal distribution. For the comparison qualitative data, we used Fisher's exact test and chi-square test. $\mathrm{p}<0.05$ was considered statistical significance threshold for the results.

\section{Results}

The demographic characteristics of the patients from both groups included in the study are summarized in Table 1. There was no significant difference between the groups in terms of age, week of gestation and BMI value.

Mean birth weight of newborns was 3259.56 \pm $403.81 \mathrm{~g}$ in Group I and 3171.40 $\pm 390.12 \mathrm{~g}$ in Group II. 
Table 1. Demographic data of the pregnant women.

\begin{tabular}{|c|c|c|c|c|c|}
\hline & \multicolumn{2}{|c|}{ Min-max values } & \multicolumn{2}{|c|}{ Mean and standard deviation } & \multirow[b]{2}{*}{$\mathbf{p}$} \\
\hline & Group I (n=102) & Group II ( $n=98)$ & Group I ( $n=102)$ & Group II (n=98) & \\
\hline Maternal age (year) & $18-38$ & $18-37$ & $23.36 \pm 4.33$ & $23.31 \pm 4.73$ & 0.663 \\
\hline Week of gestation & $37-41$ & $37-41$ & $38.54 \pm 1.40$ & $38.65 \pm 1.50$ & 0.658 \\
\hline Maternal BMI $\left(\mathrm{kg} / \mathrm{m}^{2}\right)$ & $22.14-29.91$ & $22.14-29.90$ & $26.40 \pm 2.07$ & $26.15 \pm 2.05$ & 0.390 \\
\hline
\end{tabular}

Newborns with birth weight $4000 \mathrm{~g}$ and above were defined as large. Three (2.94\%) large newborns in Group I and 4 large (4.08\%) newborns in Group II were observed. When neonatal data were analyzed, no significant difference was found among the parameters (Table 2).

In terms of hemoglobin and hematocrit values before and after labor between Group I and Group II, the data of both groups were statistically similar (Table 3).

In our study, we found the durations for first and second stages of labor $234.83 \pm 26.38$ and $75.80 \pm 15.21 \mathrm{~min}-$ utes, respectively in Group I. In Group II, the durations for first and second stages of labor were $215.10 \pm 26.61$ and $49.82 \pm 15.49$ minutes, respectively. When we compared two values, we found statistically significant difference $(\mathrm{p}<0.001)$ (Table 4).

In our study where routine episiotomy was not performed, 24 pregnant women in Group I and 31 pregnant women in Group II needed episiotomy during labor.
Perineal lacerations were observed in 91 pregnant women in Group; however, none of them was Grade 4, but only 3 cases were Grade 3. In Group II, perineal laceration was observed in 73 pregnant women; while no laceration was Grade 4, it was Grade 3 in two pregnant women. The rates of perineal lacerations were low at a statistically significant level in the group which was applied gel $(\mathrm{p}=0.009$ for those not observed at all; and $\mathrm{p}=0.015$ for Grades 1 and 2 lacerations). In terms of advanced perineal lacerations (Grades 3 and 4), there was no significant difference between the groups $(\mathrm{p}=0.622)$ (Table 5).

\section{Discussion}

It is known that the friction force between vagina and the baby is an important factor in vaginal deliver, ${ }^{[8-15]}$ it is affected by parity, and changes with substances reducing friction such as lubricants. During Ancient Greek period, Chiron promoted to use olive oil during the delivery of

Table 2. Newborn values of the groups.

\begin{tabular}{|c|c|c|c|c|c|}
\hline & \multicolumn{2}{|c|}{ Min-max values } & \multicolumn{2}{|c|}{ Mean and standard deviation } & \multirow[b]{2}{*}{$\mathbf{p}$} \\
\hline & Group I (n=102) & Group II (n=98) & Group I $(n=102)$ & Group II (n=98) & \\
\hline 1-min Apgar & $6-9$ & $8-9$ & $8.89 \pm 0.46$ & $8.85 \pm 0.22$ & 0.581 \\
\hline 5-min Apgar & $8-10$ & $9-10$ & $9.92 \pm 0.33$ & $9.97 \pm 0.173$ & 0.327 \\
\hline Birth weight (g) & $2480-4600$ & $2480-4170$ & $3259.56 \pm 403.81$ & $3171.40 \pm 390.12$ & 0.122 \\
\hline Head circumference $(\mathrm{cm})$ & $31-38$ & $33-38$ & $35.04 \pm 1.14$ & $35.02 \pm 0.76$ & 0.496 \\
\hline
\end{tabular}

Table 3. Hematologic results of the groups.

\begin{tabular}{|c|c|c|c|c|c|}
\hline & \multicolumn{2}{|c|}{ Min-max values } & \multicolumn{2}{|c|}{ Mean and standard deviation } & \multirow[b]{2}{*}{$\mathbf{p}$} \\
\hline & Group I $(n=102)$ & Group II (n=98) & Group I $(n=102)$ & Group II $(n=98)$ & \\
\hline Prenatal $\mathrm{Hb}(\mathrm{g} / \mathrm{dl})$ & $7-15$ & $9-14$ & $11.69 \pm 1.47$ & $11.59 \pm 1.27$ & 0.47 \\
\hline Prenatal Hct (\%) & $25-46$ & $30-47$ & $37.69 \pm 4.06$ & $38.24 \pm 3.58$ & 0.303 \\
\hline Postnatal Hb (g/dl) & $6-14$ & $7-13$ & $9.88 \pm 1.50$ & $9.73 \pm 1.37$ & 0.563 \\
\hline Postnatal Hct (\%) & $23-44$ & $22-42$ & $32.12 \pm 4.08$ & $32.68 \pm 4.11$ & 0.331 \\
\hline
\end{tabular}


Table 4. Labor stages of the groups.

\begin{tabular}{|c|c|c|c|c|c|}
\hline & \multicolumn{2}{|c|}{ Min-max values } & \multicolumn{2}{|c|}{ Mean and standard deviation } & \multirow[b]{2}{*}{$\mathbf{p}$} \\
\hline & Group I ( $n=102)$ & Group II (n=98) & Group I ( $n=102)$ & Group II (n=98) & \\
\hline First stage of labor (minute) & $178-312$ & $158-292$ & $234.83 \pm 26.38$ & $215.10 \pm 26.61$ & $<0.001$ \\
\hline Second stage of labor (minute) & $40-120$ & $14-94$ & $75.80 \pm 15.21$ & $49.82 \pm 15.49$ & $<0.001$ \\
\hline
\end{tabular}

horses, which is still a valid practice in veterinary medicine today. ${ }^{[16]}$

Mean age of the pregnant women in our study was $27.38 \pm 0.31$ years, and the age group $25-29$ had the highest number of patients. This was corresponding to the results of 2014 Turkey Demographic and Health Survey (TDHS). ${ }^{[17]}$ In Turkey, 64\% of the labors were carried out by pregnant women who are 30 years old or below. Compared to other similar studies, our study had relatively younger population. The mean maternal age in our study was 5 years younger than the study of Schaub et al.$^{[6]}$ and 4 years younger than the study of Ashwal et al. ${ }^{[18]}$ Similarly, in the light of the study of Eren et al. showing the adverse effects of adolescent pregnancies, which is a significant problem in Turkey, we did not include the population below 18-year-old in our study due to the potentially high perinatal problems in adolescent pregnancies. ${ }^{[19]}$

In our data, without any additional procedures (cesarean section, vaginal operative procedures or Kristeller maneuver), the first stage of labor decreased for 19 minutes $(\mathrm{p}<0.001)$ and second stage of labor decreased for 26 minutes $(\mathrm{p}<0.001)$ with the use of obstetric gel in pregnant women delivering vaginally, and this was clinically and statistically significant. By not performing epidural anesthesia in our study, we did not carry out any additional procedure which may affect the stages of labor in our cases. Stamp et al. performed per- ineal massage in their study and thus shortened the second stage of labor for 11 minutes. ${ }^{[20]}$ Similarly, Schaub et al. $^{[6]}$ used Dianatal ${ }^{\mathrm{TM}}$ obstetric gel (propylene glycol polyacrylic acid) in their multicentric randomized controlled study and shortened the second stage of the labor, reporting a significant decrease in perineal lacerations.

On the other hand, Ashwal et al. ${ }^{[18]}$ assessed 200 pregnant women, and showed that the use of obstetric gel is safe in terms of maternal and neonatal outcomes, but it has no significant contribution for the durations of labor stages or perineal integrity. In studies using propylene glycol - polyacrylic acid gel, there are differences for the methods of use. While some studies adopted single use ${ }^{[18]}$ some other studies compared the use at intervals. ${ }^{[6]}$

We used hydroxyethyl cellulose and glycerol gel, which is a new gel format with both oil- and water-based formula, in a single use. ${ }^{[2]}$ The maternal and neonatal parameters and invasive procedure rates were not statistically significant in our results. Unlike the results reported by Schaub et al..$^{[6]}$ that it may affect 1-minute Apgar score in particular, we found statistically significant difference in both 1-minute and 5-minute Apgar scores.

In our study, we found significant results in the gelapplied group especially in terms of protecting perineal integrity $(\mathrm{p}=0.009)$. Stamp ${ }^{[20]}$ and Albers ${ }^{[2]} \mathrm{K}-\mathrm{Y} \mathrm{Gel}{ }^{\circledR}$ (Johnson \& Johnson lubricant gel which contains glycerol, hydroxyethyl cellulose, gluconolactone, chlorhexidine, gluconate, methylparaben and sodium hydroxide)

Table 5. Grades of perineal lacerations and their distribution among the groups.

\begin{tabular}{|c|c|c|c|c|c|}
\hline Perineal laceration grade & \multicolumn{2}{|c|}{ Group I (n=102) } & \multicolumn{2}{|c|}{ Group II $(n=98)$} & p \\
\hline 0 (no laceration) & \multicolumn{2}{|c|}{11} & \multicolumn{2}{|c|}{25} & 0.009 \\
\hline Grade 1 & 71 & \multirow{2}{*}{ Total $n=88$} & 55 & \multirow{2}{*}{ Total $n=71$} & \multirow{2}{*}{0.015} \\
\hline Grade 2 & 17 & & 16 & & \\
\hline Grade 3 & 3 & \multirow{2}{*}{ Total $n=3$} & 2 & \multirow{2}{*}{ Total $n=2$} & \multirow{2}{*}{0.622} \\
\hline Grade 4 & 0 & & 0 & & \\
\hline Episiotomy need & \multicolumn{2}{|c|}{24} & \multicolumn{2}{|c|}{31} & 0.209 \\
\hline
\end{tabular}


could not find significant results for perineal integrity in their studies. The protection of perineal integrity can be attributed to the idiosyncratic characteristics of obstetric gel or its early use such as even during the first stage of labor. Contrarily, Schaub ${ }^{[6]}$ and Ashwal, ${ }^{[18]}$ reporting that they achieved benefits in the protection of perineum, attributed these benefits to the muco-adhesive effects of polyacrylic acid in their gels on birth canal and suggested that they managed to achieve perineal protection in this way. Mladenova et al. also used propylene glycol polyacrylic acid gel and associated their findings to the similar reasons. ${ }^{[7]}$ However, the hydroxyethyl cellulose glycerol gel we used in our study does not contain polyacrylic acid and it has no muco-adhesive effect. Since our study is monocentric, there is no procedure difference as cited in other studies. ${ }^{[0,23]}$

Rolinska et al. conducted their study on 47 pregnant women ${ }^{[23]}$ to investigate the effects of propylene glycol polyacrylic acid gel on pain and exhaustion during labor; however, they could not find any significant result. In our study, we did not investigate any psychological parameter except obstetric data.

In our study, we found no allergic reaction, infection or newborn aspiration which may be encountered due to the use of obstetric gel. In previous studies which used propylene glycol - polyacrylic acid gel, similar adverse effects were also not reported. ${ }^{[6,16,23]}$ In the light of these findings, we may suggest that the use of obstetric gel during the early moments of the first stage of labor can also be safe.

\section{Conclusion}

In our study, we observed that the use of hydroxyethyl cellulose - glycerol gel shortens the first and second stages of labor statistically and it also reduces the formation of perineal lacerations. We have concluded that obstetric labor gel does not create any positive or negative difference for episiotomy need, maternal blood loss and neonatal outcomes. The power of our study was $77.7 \%$ in the post-hoc power analysis performed on the basis of type I/II error ratio being 0.05 in terms of gel use and vaginal lacerations. We believe that this is caused by the limited number of cases in our study. We observed no maternal or neonatal adverse effect due to the use of gel during our study.

Conflicts of Interest: No conflicts declared.

\section{References}

1. Morgan DM, Cardoza P, Guire K, Fenner DE, DeLancey JO. Levator ani defect status and lower urinary tract symptoms in women with pelvic organ prolapse. Int Urogynecol J 2010;21: $47-52$.

2. Dietz HP. Levator function before and after childbirth. Aust N Z J Obstet Gynaecol 2004;44:19-23.

3. Cheng YW, Hopkins LM, Laros RK, Caughey AB. Duration of the second stage of labor in multiparous women: maternal and neonatal outcomes. Am J Obstet Gynecol 2007;196:585. e1-586.

4. Eason E, Labrecque M, Wells G, Feldman P. Preventing perineal trauma during childbirth: a systematic review. Obstet Gynecol 2000;95:464-71.

5. Beckmann MM, Stock OM. Antenatal perineal massage for reducing perineal trauma. Cochrane Database Syst Rev 2013;(4):CD005123.

6. Schaub, AF, Litschgi, M, Hoesli, I, Holzgreve, W, Bleul, U, Geissbühler, V. Obstetric gel shortens second stage of labor and prevents perineal trauma in nulliparous women: a randomized controlled trial on labor facilitation. J Perinat Med 2008;36:129-35.

7. Mladenova M, Dimitrakova E, Amaliev G, Pehlivanov B. The role of Dianatal Obstetric Gel in normal labor. [Article in Bulgarian] Akush Ginekol (Sofiia) 2012;51:58-9.

8. Andrews CM. Changing fetal position through maternal posturing. Birth Defects Orig Artic Ser 1981;17:85-96.

9. Furuya H, Hashimoto T, Kokuho K, Kino H, Fukamauchi K. Pressures on the human fetus during labor - intrauterine and on the fetal head. [Article in Japanese] Nihon Sanka Fujinka Gakkai Zasshi 1981;33:2173-81.

10. Lindgren L, Holmlund D. Friction between the fetal head and uterine wall during normal labor and lower uterine spasm. Am J Obstet Gynecol 1969;103:939-41.

11. Manassiev N. Head-to-cervix force: an important physiological variable in labor. Br J Obstet Gynaecol 1997;104:272-3.

12. Martius G. Roederer's head attitude resulting from soft tissue anomalies. Contribution to the significance of soft tissue dystocia. [Article in German] Geburtshilfe Frauenheilkd 1970;30: 356-61.

13. Moolgaoker AS, Ahamed SO, Payne PR. A comparison of different methods of instrumental delivery based on electronic measurements of compression and traction. Obstet Gynecol 1979;54:299-309.

14. Rempen A, Kraus M. Pressures on the fetal head during normal labor. J Perinat Med 1991;19:199-206.

15. Sallam HN, Abdel-Dayem A, Sakr RA, Sallam A, Loutfy I. Mathematical relationships between uterine contractions, cervical dilatation, descent and rotation in spontaneous vertex deliveries. Int J Gynaecol Obstet 1999;64:135-9.

16. Ahlers D. Rechtsfragen in der Geburtshilfe. In: Grunert E, Arbeiter K, Ahlers D, editors. Richter-Goetze Tiergeburtshilfe. 4. Aufl. Berlin: Paul Parey Verlag; 1993. p. 603-23.

17. Hacettepe Üniversitesi Nüfus Etütleri Enstitüsü. 2014 Türkiye Nüfus ve Sağlık Araştırması. Ankara: Hacettepe Üniversitesi; 2014. 
18. Ashwal E, Aviram A, Wertheimer A, Krispin E, Kaplan B, Hiersch L. The impact of obstetric gel on the second stage of labor and perineal integrity: a randomized controlled trial. J Matern Fetal Neonatal Med 2016;29:3024-9.

19. Eren EC, Ekiz A, Mumusoglu S, Yildirim D, Aydiner B, Bestel $M$, et al. Adverse perinatal outcomes of adolescent pregnancies in one center in İstanbul, Turkey. Clin Exp Obstet Gynecol 2015;42:752-6.

20. Stamp G, Kruzins G, Crowther C. Perineal massage in labour and prevention of perineal trauma: randomised controlled trial. BMJ 2001;322:1277-80.
21. Natalis Obstetrik Jel Prospektüs bilgileri (2015) Health Care Switzerland. Konya: Sedomed Medikal İlaç Ltd. Şti.; 2015.

22. Albers LL, Sedler KD, Bedrick EJ, Teaf D, Peralta P. Midwifery care measures in the second stage of labor and reduction of genital tract trauma at birth: a randomized trial. J Midwifery Womens Health 2005;50:365-72.

23. Rolinska AA, Tomasz G, Kwasniewska A, Makara-Studzinska M. Searching for medical substances safe for mother and child, facilitating the delivery of pain management and decreasing exhaustion - Evaluation of obstetric gel by pregnant women. Pain Manag Nurs 2015;16:493-8. 